\title{
Correction to: Yes, they can: polar bears Ursus maritimus successfully hunt Svalbard reindeer Rangifer tarandus platyrhynchus
}

\author{
Lech Stempniewicz $^{1}$ [D $\cdot$ Izabela Kulaszewicz ${ }^{2}$. Jon Aars ${ }^{3}$
}

Published online: 30 November 2021

(c) The Author(s) 2021

\section{Correction to: Polar Biology (2021) 44:2199-2206 \\ https://doi.org/10.1007/s00300-021-02954-w}

In the original publication of the article, the caption of the

Fig. 3 was published incorrectly.
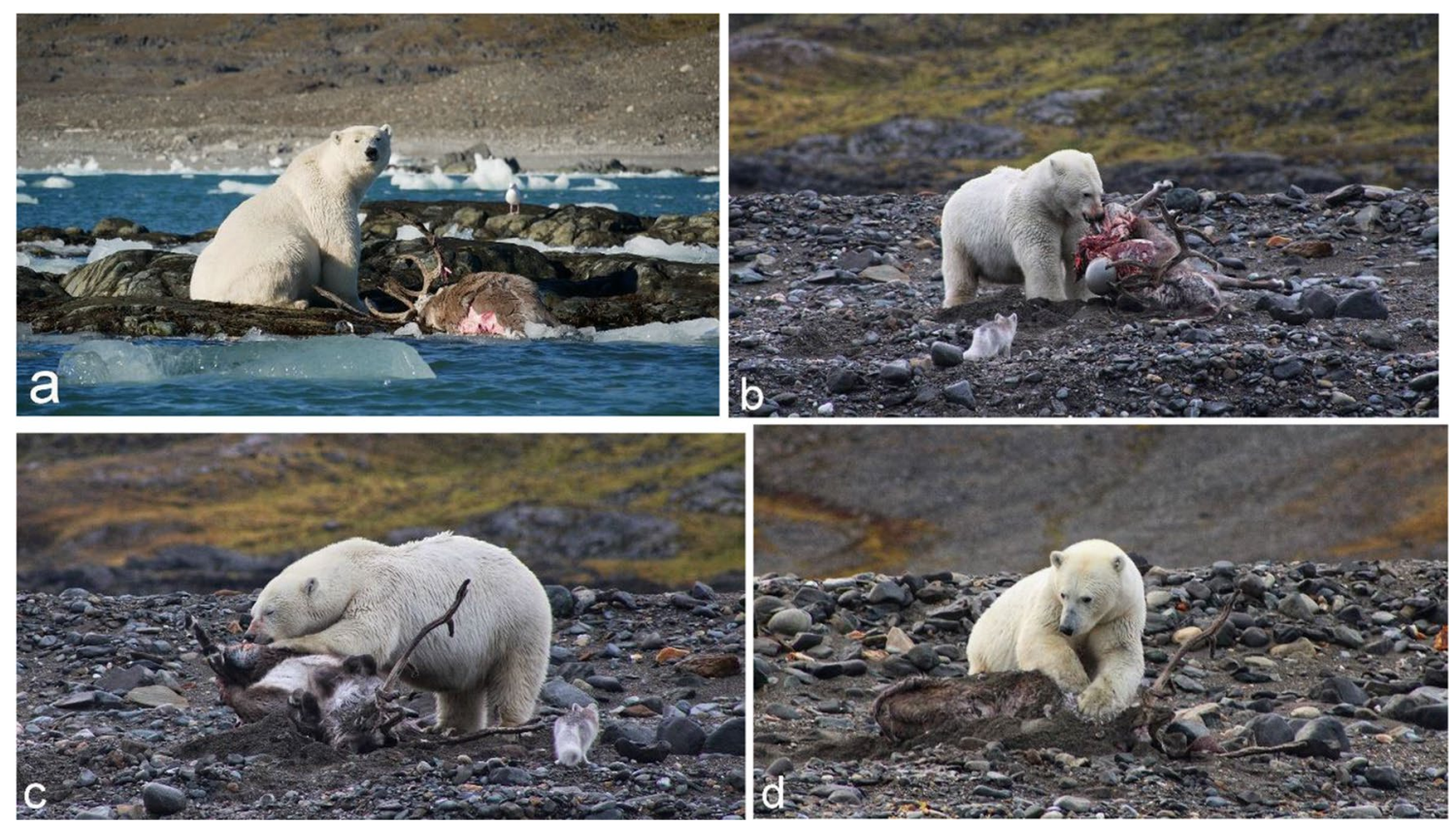

Fig. 3 Polar bear Ursus maritimus with a killed reindeer Rangifer tarandus platyrhynchus on skerries (a), dragging it on to the beach (b), eating it (c) and trying to bury it (d). Photos: P. Klicz and P. Nowosad

The original article can be found online at https://doi.org/10.1007/ s00300-021-02954-w.

Lech Stempniewicz

lech.stempniewicz@ug.edu.pl

1 Department of Vertebrate Ecology and Zoology, Faculty of Biology, University of Gdańsk, Wita Stwosza 59, 80-308 Gdańsk, Poland
Institute of Geophysics, Polish Academy of Sciences (IG PAS), Polish Polar Station Hornsund, Księcia Janusza 64, 01-452 Warsaw, Poland

3 Fram Centre, Norwegian Polar Institute, 9296 Troms $\varnothing$, Norway 
The correct caption is given in this correction.

The original article has been corrected.

Open Access This article is licensed under a Creative Commons Attribution 4.0 International License, which permits use, sharing, adaptation, distribution and reproduction in any medium or format, as long as you give appropriate credit to the original author(s) and the source, provide a link to the Creative Commons licence, and indicate if changes were made. The images or other third party material in this article are included in the article's Creative Commons licence, unless indicated otherwise in a credit line to the material. If material is not included in the article's Creative Commons licence and your intended use is not permitted by statutory regulation or exceeds the permitted use, you will need to obtain permission directly from the copyright holder. To view a copy of this licence, visit http://creativecommons.org/licenses/by/4.0/.

Publisher's Note Springer Nature remains neutral with regard to jurisdictional claims in published maps and institutional affiliations. 